\title{
De la collecte en milieu urbain chez les Mataco (Chaco argentin)
}

\section{François-René Picon}

\section{(2) OpenEdition \\ 12 Journals}

Édition électronique

URL : https://journals.openedition.org/tc/418

DOI : $10.4000 /$ tc. 418

ISSN : 1952-420X

Éditeur

Éditions de l'EHESS

\section{Édition imprimée}

Date de publication : 1 avril 1999

ISSN : 0248-6016

\section{Référence électronique}

François-René Picon, « De la collecte en milieu urbain chez les Mataco (Chaco argentin) », Techniques \& Culture [En ligne], 31-32 | 1999, mis en ligne le 26 octobre 2005, consulté le 29 septembre 2022.

URL : http://journals.openedition.org/tc/418; DOI : https://doi.org/10.4000/tc.418

Ce document a été généré automatiquement le 29 septembre 2022.

Tous droits réservés 


\section{De la collecte en milieu urbain chez les Mataco (Chaco argentin)}

François-René Picon 